\title{
Determination of seasonal variation in reference evapotranspiration using regression analysis
}

\author{
Kadri YÜREKLí1 ${ }^{1}$, Mehmet Murat CÖMERT1ㅜ, Müberra ERDOĞAN ${ }^{1}$, Saniye DEMİR ${ }^{2}$ \\ ${ }^{1}$ University of Gaziosmanpaşa, Faculty of Agriculture, Department of Biosystem Engineering, Tokat \\ ${ }^{2}$ University of Gaziosmanpasa, Faculty of Agriculture, Department of Soil Science and Plant Nutrition, Tokat
}

Alınış tarihi: 12 Temmuz 2018, Kabul tarihi: 13 Aralık 2018

Sorumlu yazar: Mehmet Murat CÖMERT, e-posta: mehmetmurat.comert@gop.edu.tr

\begin{abstract}
In the study, variability in reference evapotranspiration (ET $)_{0}$ from Southeastern Anatolian Project (GAP) area was investigated with linear regression method. For the purpose, seasonal $\mathrm{ET}_{0}$ time series were formed from monthly reference evapotranspiration $\left(\mathrm{ET}_{0}\right)$. The $\mathrm{ET}_{0}$ data sets of three sites showed a statistically significance decreasing trend while there was upward trend in some seasons of two sites. But, variation in all seasonal $\mathrm{ET}_{0}$ time series of Kilis site was not detected.
\end{abstract}

Key words: GAP, reference evapotranspiration, regression analysis

Referans bitki su tüketimindeki mevsimsel değişimin regresyon analizi ile belirlenmesi

\section{Öz}

$\mathrm{Bu}$ çalışmada, Güneydoğu Anadolu Projesi (GAP) bölgesinde referans bitki su tüketimindeki değişim lineer regresyon yöntemi ile incelenmiştir. $\mathrm{Bu}$ amaçla aylık referans bitki su tüketiminden mevsimlik $\mathrm{ET}_{0}$ zaman serileri oluşturulmuştur. İki şehirde $\mathrm{ET}_{0}$ veri kümeleri bazı mevsimlerde artan trend gösterirken, üç şehirde istatistiki anlamda önemli bir azalan trend göstermiştir. Ancak Kilis'de tüm mevsimlik $\mathrm{ET}_{0}$ zaman serilerinde değişim saptanmamıştır.

Anahtar kelimeler: GAP, referans bitki su tüketimi, regresyon analizi

\section{Introduction}

Rapid population growth, urbanization, deforestation, and especially after the industrial revolution, as a result of the rapid consumption of fossil fuels, increase of the greenhouse gases emitted to the atmosphere has had a significant impact on the hydrological cycle. It is foreseen by climate scientists that global warming, resulting from greenhouse gas emissions which has a significant impact on climate system, would affect Turkey as style in drought. In this sense, the effective use of our limited water resources potential has become more important than yesterday. Approximately $75 \%$ of the available water is used in agriculture in our country.

This means that the more damage than the expected drought will occur in agricultural sector. Even more importantly, this unpleasant situation would make us dependent on foreign countries in terms of agricultural products. Due to such a serious problem, the importance of the optimal and uncontaminated use of our existing water resources in Turkey should be grasped by our citizens. However, the water, which is an indispensable part of life, is also the most important ingredient in the production of clean energy. Accurate analysis of the impact of the threat of global warming on our country should be made and it is necessary to take measures accordingly to benefit from our water resources efficiently.

Changes in precipitation are often analyzed when assessing the likely impact of climate change on ecosystems. However, amount of rainfall during the year vary significantly according to months. Especially the months of July and August is 
inherently arid, as a results of this case, there seems to an increasing trend due to heavy rainfall occurred in these months of some years. In other words, the analysis, which is related to rainfall, do not fully reflect the natural structure of such months. Severity of the drought will significantly increase with increasing temperature. Some researchers suggest that the use of reference evapotranspiration $\left(\mathrm{ET}_{0}\right)$ values is more accurate in assessing impact of global warming and other factors on climate elements. Change in climate or atmospheric conditions are considered to be directly reflected in $\mathrm{ET}_{0}$. Espadafor et al. (2011) in Spain, Dinpashoh et al. (2011) in Iran and Tang et al. (2011) in China investigated the effect of climate change on $\mathrm{ET}_{0}$. Yurekli et al. (2017) evaluated the existence of an available monotonic trend in seasonal $\mathrm{ET}_{0}$ data predicted for five provinces in the Middle Anatolian Region by using the Holt's approach and unit root test.

This study were conducted on detecting variation in seasonal $\mathrm{ET}_{0}$ data sequences calculated for seven sites in the region of Southeastern Anatolian Project (GAP). The study was carried out by applying linear regression method (LRM) to the seasonal data sets.

\section{Material and Methods}

The GAP project is the greatest investment in the sense of regional development in Turkey and the fourth most comprehensive irrigation project in the world. The development of the GAP region was originally devised based on its water and land resources. Therefore, the potential drought risk to the region would reduce the chance of the project which consists of 13 groups of irrigation and energy projects, in reaching the targeted criteria.

Climate components were used to constitute $\mathrm{ET}_{0}$ data sequences as material in the study. The study area includes 9 provinces in which 9 meteorological stations (site) are operated by Turkish State Meteorological Service and the data needed for analysis were obtained from these stations. But, seven stations, called as Gaziantep, Sanliurfa, Diyarbakir, Siirt, Adiyaman, Kilis and Batman, were considered instead of nine stations in the region due to too many missing values on the two stations (Mardin and Sirnak). The geographical positions of these stations on the region are given in the Figure 1. Analysis data was generated for each station in seasonal periods, namely period one (from January to March, P-I), period two (from April to June, P-II), period three (from July to September, P-III), period four (from October to December, P-IV). As the first step in the study, the reference evapotranspiration $\left(\mathrm{ET}_{0}\right)$ is estimated with the FA056 Penman-Monteith methodology, the detailed description of which there is in the reference of Allen et al. (1998). Seasonal data was formed by summing up monthly $\mathrm{ET}_{0}$ series in seasonal periods for each rain gauge station after calculation of monthly $\mathrm{ET}_{0}$. Parametric and nonparametric statistic approaches is often used to reveal whether hydrologic and-meteorological data has non-stationary (e.g., Abdul Aziz and Burn 2006; Espadafor et al. 2011; Hamed 2008; Liang et al. 2010; Tabari and Talae 2011).

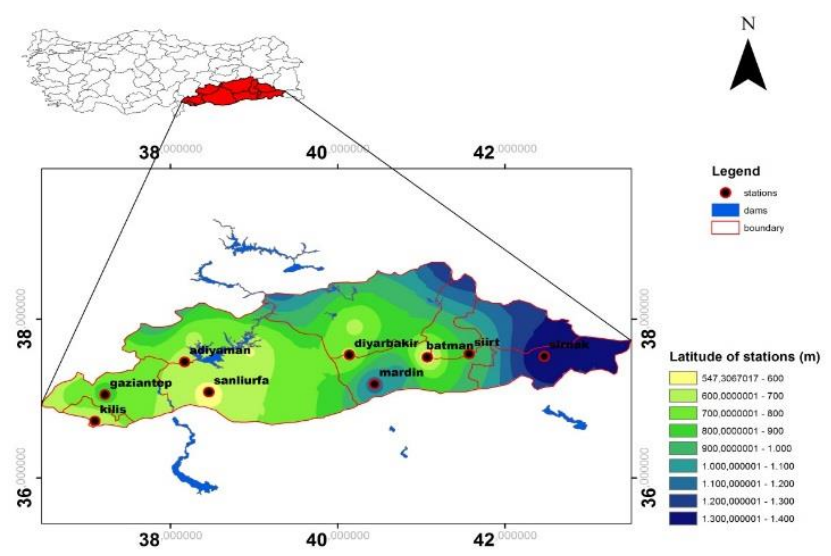

Figure 1. The geographical positions of the stations on the GAP project region

The use of LRM in trend detection is based on the correlation between independent variable $(\mathrm{x})$ and dependent variable (y) which is designated by independent variable as $\mathrm{y}_{\mathrm{i}}$ is predicted by $\mathrm{x}_{\mathrm{i}}$ (Jaiswal, et al., 2015). In the basic mentality of LRM, a straight line is fit to scatter of the values associated with a given data set on a cartesian coordinate system whose axes is composed of independent and dependent variables on the $\mathrm{x}$-axis and the $\mathrm{y}$-axis, respectively. For a given $\mathrm{n}$ time series $\left(\mathrm{x}_{1}, \mathrm{x}_{2}, \mathrm{x}_{3}\right.$, $\left.\ldots, \mathrm{x}_{\mathrm{n}}\right)$, the equations of a straight line and LRM test are given below.

$$
\begin{aligned}
& y=a+b x \\
& a=\bar{y}-b \bar{x} \\
& b=\frac{\sum_{i=1}^{n}\left(x_{i}-\bar{x}\right)\left(y_{i}-\bar{y}\right)}{\sum_{i=1}^{n}\left(x_{i}-\bar{x}\right)^{2}}
\end{aligned}
$$




$$
\begin{aligned}
& S_{L R M}=\frac{b}{\sigma} \\
& \sigma=\sqrt{\frac{12 \sum_{i=1}^{n}\left(y_{i}-a-b x_{i}\right)}{n(n-2)\left(n^{2}-1\right)}}
\end{aligned}
$$

In the above relationships, $\mathrm{y}, \mathrm{a}, \mathrm{b}$ and $\mathrm{S}_{\mathrm{LRM}}$ parameters are the straight line equation, intercept, regression gradient, test statistic. The test statistic follows the student's $t$ distribution with $n-2$ degrees of freedom. The null hypothesis $\left(\mathrm{H}_{0}\right)$ associated with LRM test is that there is no trend in the data set. Alternative hypothesis $\left(\mathrm{H}_{1}\right)$ is that the considered data has a monotonic trend. The statistically acceptance of the null hypothesis prevails when the $\mathrm{S}$ test value obtained from Equation 4 is smaller in absolute value than the table critical value of the student's $t$ distribution at the $5 \%$ significance level.
Eventually, the available data is judged to have no a monotonic trend.

\section{Results}

Under the condition in which the hydrometeorogical observations are non-normally distributed, Pearson and Please (1975) stated that there was invalidity in analysis realized based on the statistical tests such as the $t$ and $F$ test. To use LRM test in trend analysis, it is necessary that the data set to analyze should have the normal distribution. Therefore, the test of whether the available data was normally distributed was performed before being passed to the use of the LRM test. The KolmogorovSmirnov (KS) normality method was selected for the aim. The results regarding the KS is given in the Table 1. The results of all data sets indicate that the seasonal $\mathrm{ET}_{0}$ data sequences are normally distributed. In the table, ZKS and P is related to Kolmogorov-Smirnov test statistic value and its probability level, respectively.

\begin{tabular}{|c|c|c|c|c|c|c|c|c|}
\hline \multirow{2}{*}{ Station } & \multicolumn{2}{|c|}{ Period one (P-I) } & \multicolumn{2}{|c|}{ Period two (P-II) } & \multicolumn{2}{|c|}{ Period three (P-III) } & \multicolumn{2}{|c|}{ Period four (P-IV) } \\
\hline & $\mathrm{Z}_{\mathrm{KS}}$ & $\mathrm{P}$ & $\mathrm{Z}_{\mathrm{KS}}$ & $\mathrm{P}$ & $\mathrm{Z}_{\mathrm{KS}}$ & $\mathrm{P}$ & $\mathrm{Z}_{\mathrm{KS}}$ & $\mathrm{P}$ \\
\hline Gaziantep & 0.521 & 0.949 & 0.796 & 0.55 & 0.905 & 0.386 & 0.964 & 0.311 \\
\hline Sanlıurfa & 0.78 & 0.577 & 0.732 & 0.658 & 0.951 & 0.326 & 0.793 & 0.556 \\
\hline Diyarbakır & 0.470 & 0.980 & 0.648 & 0.796 & 1.156 & 0.138 & 0.797 & 0.549 \\
\hline Siirt & 0.846 & 0.471 & 0.693 & 0.722 & 1.157 & 0.137 & 0.510 & 0.957 \\
\hline Adıyaman & 0.929 & 0.355 & 0.971 & 0.302 & 0.643 & 0.803 & 0.573 & 0.898 \\
\hline Kilis & 0.518 & 0.951 & 0.620 & 0.837 & 1.010 & 0.260 & 0.413 & 0.996 \\
\hline Batman & 0.562 & 0.910 & 0.616 & 0.842 & 1.107 & 0.172 & 0.690 & 0.728 \\
\hline
\end{tabular}

Table 1. The normality results of seasonal $\mathrm{ET}_{0}$ data sequences

\begin{tabular}{|c|c|c|c|c|c|c|c|c|}
\hline \multirow{2}{*}{ Station } & \multicolumn{2}{|c|}{ Period one (P-I) } & \multicolumn{2}{|c|}{ Period two (P-II) } & \multicolumn{2}{|c|}{ Period three (P-III) } & \multicolumn{2}{|c|}{ Period four (P-IV) } \\
\hline & $\mathrm{S}_{\mathrm{LRM}}$ & $\mathrm{t}_{\text {-critical }}$ & $\mathrm{S}_{\mathrm{LRM}}$ & $t_{\text {-critical }}$ & $\mathrm{S}_{\mathrm{LRM}}$ & $t_{\text {-critical }}$ & $\mathrm{S}_{\mathrm{LRM}}$ & $\mathrm{t}_{\text {-critical }}$ \\
\hline Gaziantep & -9.14 & 2.011 & -14.76 & 2.011 & -21.88 & 2.011 & -14.79 & 2.011 \\
\hline Sanliurfa & -2.06 & 2.011 & -2.04 & 2.011 & -6.567 & 2.011 & -4.050 & 2.011 \\
\hline Diyarbakir & 2.835 & 2.013 & 2.484 & 2.013 & 1.566 & 2.013 & 2.720 & 2.013 \\
\hline Siirt & -8.23 & 2.011 & -12.48 & 2.011 & -22.71 & 2.011 & -12.53 & 2.011 \\
\hline Adiyaman & -7.04 & 2.017 & -6.75 & 2.017 & -11.33 & 2.017 & -9.15 & 2.017 \\
\hline Kilis & -0.355 & 2.064 & -1.702 & 2.064 & -1.422 & 2.064 & 1.029 & 2.064 \\
\hline Batman & 1.789 & 2.069 & 1.600 & 2.069 & 1.888 & 2.069 & 2.286 & 2.069 \\
\hline
\end{tabular}

Table 2. The LRM test results of seasonal $\mathrm{ET}_{0}$ data sequences

The LRM test to detect monotonic trend in the seasonal $\mathrm{ET}_{0}$ data sets from meteorological stations of seven sites was applied after normality analysis. The results of the LRM test are given in the Table 2 . In the table, the data set having monotonic trend being statistically significant is in the bold character. The Seasonal $\mathrm{ET}_{0}$ data of Gaziantep, Sanliurfa, Adiyaman and Siirt sites has a downward trend while there is an increasing monotonic trend in there seasonal $\mathrm{ET}_{0}$ data of Diyarbakir site. The $\mathrm{ET}_{0}$ data in the period three of Diyarbakir site showed a statistically insignificant change because the calculated value or test statistic value ( $S_{\text {LRM }}$ ) is smaller than the critical table value ( $\mathrm{t}$-critical) of the student's $t$ distribution at 5\% confidence level. None of all $\mathrm{ET}_{0}$ data sequences belonging to Kilis site had a statistically significance upward and downward trend, whereas significant increasing trend in the $\mathrm{ET}_{0}$ data dealing with the period four of Batman site was detected. But, there was no change in three seasonal $\mathrm{ET}_{0}$ data sets of Batman site.

\section{Conclusion}

This study was conducted on the seasonal $\mathrm{ET}_{0}$ data sequences calculated based on meteorological data 
sets of seven sites in Southeastern Anatolian Project (GAP) region. As to why this region was selected for research, the main target in the project is to extinguish socio-economic disparities among all region in Turkey. This was planned on the development of soil and water resources. Climate variability in the area having dominant arid and semi-arid climate would cause the project to fail. In this sense, information on climatic variability should be gathered and the necessary measures should be taken.

In the study, climate variability in the GAP project area was explored by linear regression method (LRM). For the aim, seasonal $\mathrm{ET}_{0}$ time series were calculated by FAO Penman-Monteith approach.

The all $\mathrm{ET}_{0}$ data sets of four sites, named Gaziantep, Sanliurfa, Adiyaman and Siirt, had a significant downward trend. But, statistically significance upward trend in the three seasons for Diyarbakir site and one season for Batman site were revealed while there was monotonic trend in none of seasonal $\mathrm{ET}_{0}$ data sets for Kilis site. The results from the LRM show that there may be a threat in the context of water resources and agricultural production.

\section{References}

Abdul Aziz, O.I., Burn, D.H., 2006. Trends and variability in the hydrological regime of the Mackenzie River Basin. Journal of Hydrology, 319: 282-294.

Allen, R.G., Pereira, L.S., Raes D., Smith, M., 1998. Crop Evapotranspiration (guidelines for computing crop water requirements): FAO Irrigation and Drainage Paper No. 56.

Dinpashoh, Y., Jhajharia, D., Fakheri-Fard, A., Singh, V.P., Kahya, E., 2011. Trends in reference crop evapotranspiration over Iran. J. Hydrol. 399: 422433.

Espadafor, M., Lorite, I.J., Gavilán, P., Berengena, J., 2011. An analysis of the tendency of reference evapotranspiration estimates and other climate variables during the last 45 years in Southern Spain. Agric. Water. Manage. 98: 1045-1061.

Hamed, K.H., 2008. Trend detection in hydrologic data: The Mann-Kendall trend test under the scaling hypothesis. Journal of Hydrology, 349: 350-363.

Jaiswal, R.K., Lohani, A.K, Tiwari, H.L. 2015. Statistical analysis for change detection and trend assessment in climatological parameters. Environmental Processes, 2(4): 729-749.

Liang, L.Q., Li, L.J., Liu, Q., 2010. Temporal variation of reference evapotranspiration during 1961-2005 in the Taoer River Basin of Northest China. Agricultural and Forest Meteorology, 150: 298306.

Pearson, E.S., Please, N.W., 1975. Relation Between the Shape of Population Distribution and the Robustness of Four Simple Statistical Tests. Biometrika 62: 223-241.

Tabari, H., Talaee, P.H., 2011. Temporal variability of precipitation over Iran: 1966-2005. Journal of Hydrology, 396, 313-320.

Tang, B., Tong, L., Kang, S., Zhang, L., 2011. Impacts of climate variability on reference evapotranspiration over 58 years in the Haihe river basin of north China. Agric. Water Manage. 98: 1660-1670.

Yürekli, K., Ünlükara, A., Cömert, M.M., 2017. “Holt Yaklaşımı ile Referans Bitki Su Tüketiminin Mevsimsel Değișiminin Saptanması," Gaziosmanpasa Journal of Scientific Research, 6(special issue), 75-81. 